\title{
A comparative study to assess knowledge, attitude and practice for Hepatitis B vaccination among Nurses of Government and Private Hospital of Central India
}

\author{
Saroshe S. ${ }^{1 *}$, Pandey D. ${ }^{2}$, Dixit S. ${ }^{3}$, Bansal S. ${ }^{4}$, Shivram G. ${ }^{5}$ \\ DOI: https://doi.org/10.17511/ijphr.2014.i1.05
}

\footnotetext{
1* Satish Saroshe, Assistant Professor, Department of Community Medicine, MGM Medical College, Indore, Madhya Pradesh, India.

2 Dhruvendra Pandey, Resident, Department of Community Medicine, MGM Medical College, Indore, Madhya Pradesh, India.

3 Sanjay Dixit, Professor \& Head, Department of Community Medicine, MGM Medical College, Indore, Madhya Pradesh, India.

${ }^{4}$ S B Bansal, Associate Professor, Department of Community Medicine, MGM Medical College, Indore, Madhya Pradesh, India.

5 Geeta Shivram, Demontrator, Department of Community Medicine, MGM Medical College, Indore, Madhya Pradesh, India.
}

Background: Hepatitis B is a global public health problem. In India the carrier rate of hepatitis B is higher among health care personnel. Nurses are probably the most commonly exposed health care staff exposed to needle prick, injuries and contact with infectious fluids. Objective: To assess the levels of awareness regarding infectivity of hepatitis B among nurses, their attitude towards hepatitis $B$ vaccination and practices followed after needle stick injury. Methodology: A cross sectional observational study was conducted in 30 nurses of MY hospital (MYH) and multispecialty private hospital $(\mathrm{PH})$ each with help of semi structured questionnaire about knowledge, attitude and practice related to hepatitis $\mathrm{B}$. Chi square test was applied to assess significant difference between the two centres. Result: $73.3 \%$ of nurses of $\mathrm{MYH}$ and $43.3 \%$ of $\mathrm{PH}$ think that they are at high risk for hepatitis $\mathrm{B}$ infection. $43.3 \%$ of $\mathrm{MYH}$ and $23.3 \%$ of $\mathrm{PH}$ considered all hospital places to be risky. $30 \%$ nurses of $\mathrm{MYH}$ and $20 \%$ of $\mathrm{PH}$ had knowledge of post exposure prophylaxis. $36.67 \%$ of nurses of $\mathrm{MYH}$ and $93.33 \%$ nurses of $\mathrm{PH}$ were vaccinated. Conclusion: This study was concluded as vaccination was more in private institution than government institution. Main reason or the acceptance of vaccination is Hospital policy. Knowledge about post exposure prophylaxis and correct action after needle stick injuries was less.

Keywords: Hepatitis B, Health care workers, Nurses, Post exposure prophylaxis, Universal Precautions, Needle Stick Injuries

Corresponding Author

Satish Saroshe, Assistant Professor, Department of Community Medicine, MGM Medical College, Indore, Madhya Pradesh, India.

Email: drsatishsaroshe@gmail.com
How to Cite this Article

To Browse
Saroshe S, Pandey D, Dixit S, Bansal SB, Shivram G. A comparative study to assess knowledge, attitude and practice for Hepatitis B vaccination among Nurses of Government and Private Hospital of Central India. Public Health Rev Int J Public Health Res. $2014 ; 1(1): 25-31$.

Available From

https://publichealth.medresearch.in/index.php/ijphr/ article/view/5

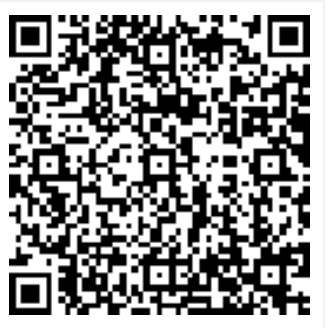




\section{Introduction}

Hepatitis B is a leading cause of chronic hepatitis, cirrhosis and hepatocellular carcinoma [1-4]. Hepatitis B previously known as serum hepatitis is an inflammatory disease of the liver caused by Hepatitis B virus (HBV) and is a global public health problem.

Nearly two billion people in the world have been acutely infected by HBV and there are nearly 350 million people chronically infected. [1] In South East Asian Region, there are estimated 80 million HBV carriers (about $6 \%$ of the total population). [5, 6] $\mathrm{HBV}$ is a DNA virus belonging to the virus family Hepadnaviridae. HBV enters the liver via the bloodstream and replication occurs only in the liver tissue. The virus is $42-47 \mathrm{~nm}$ in diameter and circulates in the blood in concentrations as high as 108 virions per $\mathrm{ml}$.

HBV is transmitted by percutaneous or mucosal exposure to infected blood or other body fluids through numerous routes: perinatal, mother to child, sexual, needle-sharing, and occupational/health-care-related. $[4,7,8]$ India has the intermediate endemicity of Hepatitis $B$ with Hepatitis B surface antigen ( $\mathrm{HBsAg}$ ) prevalence between $2 \%$ and $10 \%$ among the population studied. The number of carriers in India has been estimated to be over 40 millions $[5,6]$.

In India the carrier rate are higher among health care personnel $(10.87 \%)$ as compared to the blood donors (6\%) and general public (5\%). Among healthcare workers seroprevalence is two to four times higher than that of the general population. [9] Hepatitis B infections may occur in the health care settings due to lapse in the sterilization technique of instruments or due to the improper hospital waste management because 10 to $20 \%$ of health care waste is hazardous which may create a variety of health risks [10].

The majority of the infections are subclinical, so approximately $80 \%$ of all HBV infections are undiagnosed. [4] Among the health care personnel, HBV is transmitted by skin prick with infected, contaminated needles and syringes or through accidental inoculation of minute quantities of blood during surgical, gynaecological and dental procedures.[6] Nurses are probably the most common health care staff exposed to needle prick injuries and contact with infectious fluids.
They are exposed to this risk right from there student career. Hence it is important that nurses as well as nursing students should have a thorough knowledge regarding Hepatitis $B$ to minimize the health care settings acquired infections among them and other health personnel. [11]

With this background aim of this study is to assess the levels of awareness regarding infectivity of hepatitis B virus in nurses of government and private hospital, their vaccination status, their attitude towards hepatitis $B$ vaccination and their compliance with universal precautions.

\section{Methodology}

A cross sectional observational study was conducted in urban area of Indore. Nurses working at tertiary care Government Medical college hospital (Maharaja Yashwantrao Hospital (MYH)) and a busy private Multispecialty hospital (Private Hospital $(\mathrm{PH})$ ) were selected for study. Study duration was 4 month (Oct 2011 to Feb 2012). All the nurses working at the respective centre for at least for 3 years were included in the study and those which were not give consent for study and non nursing health care personal were excluded from the study.

Sample size for Number of nurses working at Private Hospital $(\mathrm{PH})$ was calculated using formula $\mathrm{N}=\mathrm{Z} 2[\mathrm{P}$ $(1-P)] / d 2$, d (width of confidence interval) was determine to be $10 \%, Z=1.96$ ( $5 \%$ precision), $P$ (desired response distribution) $=50 \%$. Sample size comes out to be 30 for population of 42 nurses (eligible according to inclusion criteria). To maintain the comparability 30 nurses working at MY hospital were selected. The selection of desired number of nurses is done by Simple Random Sampling using random number table. A semi structured questionnaire was used which include 19 standard question, related to their hepatitis b vaccination, what they will done if they got the exposure and follows the guideline of universal precaution. Written informed consent was obtained. Data entry and analysis was carried out using appropriate statistical software (MS Excel and SPSS). Chi square test was applied and $\mathrm{p}<0.05$ was considered to be statistically significant.

\section{Results}

A total of 42 nurses were working for more than 3 years in Private Hospital (PH), out of which 30 were included in this study. $15(50 \%)$ nurses of $\mathrm{MYH}$ and 20 (66.67) nurses of Private Hospital (PH) were in 
35-45 years age group and married. All the nurses included in study were graduated in nursing training. (Table 1)

Table 1: Showing distribution of Age and Marital Status

\begin{tabular}{|l|l|l|l|l|}
\hline & \multicolumn{2}{|c|}{ MYH Hospital Nurses } & \multicolumn{2}{|c|}{ Private Hospital Nurses } \\
\hline $\begin{array}{l}\text { Age Group } \\
\text { (Years) }\end{array}$ & $\begin{array}{l}\text { Married No. } \\
(\%)\end{array}$ & $\begin{array}{l}\text { Unmarried No. } \\
(\%)\end{array}$ & $\begin{array}{l}\text { Married No. } \\
(\%)\end{array}$ & $\begin{array}{l}\text { Unmarried No. } \\
(\%)\end{array}$ \\
\hline $25-35$ & $2(6.67)$ & $2(6.67)$ & $3(10)$ & $5(16.67)$ \\
\hline $35-45$ & $15(50)$ & $1(3.33)$ & $20(66.66)$ & 0 \\
\hline $45-55$ & $8(26.66)$ & 0 & $2(6.67)$ & 0 \\
\hline $55-65$ & $2(6.67)$ & 0 & 0 & 0 \\
\hline Total & $27(90)$ & $3(10)$ & $25(83.33)$ & $5(16.67)$ \\
\hline
\end{tabular}

Knowledge

Table 2: Showing Comparison regarding knowledge about they being at high risk of hepatitis B infection*

\begin{tabular}{|l|l|l|l|l|}
\hline \multirow{2}{*}{$\begin{array}{c}\text { knowledge about they being } \\
\text { at high risk of infection }\end{array}$} & \multicolumn{2}{|c|}{$\begin{array}{c}\text { MYH Hospital } \\
\text { Nurses }\end{array}$} & \multicolumn{2}{c|}{$\begin{array}{c}\text { Private Hospital } \\
\text { Nurses }\end{array}$} \\
\cline { 2 - 5 } & Numbers & Percentage & Numbers & Percentage \\
\hline Yes & 22 & 73.33 & 13 & 43.33 \\
\hline No & 8 & 26.67 & 17 & 56.67 \\
\hline Total & 30 & 100 & 30 & 100 \\
\hline
\end{tabular}

$* \mathrm{x} 2=5.54 ; \mathrm{df}=1 ; \mathrm{p}$ value $=0.018 ;$ statistically significant

All the nurses of $\mathrm{MYH}$ and $\mathrm{PH}$ were knew about hepatitis $B$ as it is a viral infection, lead to fatal outcome. $22(73.3 \%)$ of nurses of $\mathrm{MYH}$ and 13 (43.3\%) of $\mathrm{PH}$, think that they are at high risk for hepatitis B infection. (Table 1) 16 (53.3\%) nurses of MYH and 12 (40\%) of $\mathrm{PH}$ knew about needle stick being a mode of transmission. 29 (96.6\%) of $\mathrm{MYH}$ and $27(90 \%)$ of $\mathrm{PH}$ nurses knew that blood transmission being a mode of transmission (Figure $1)$.

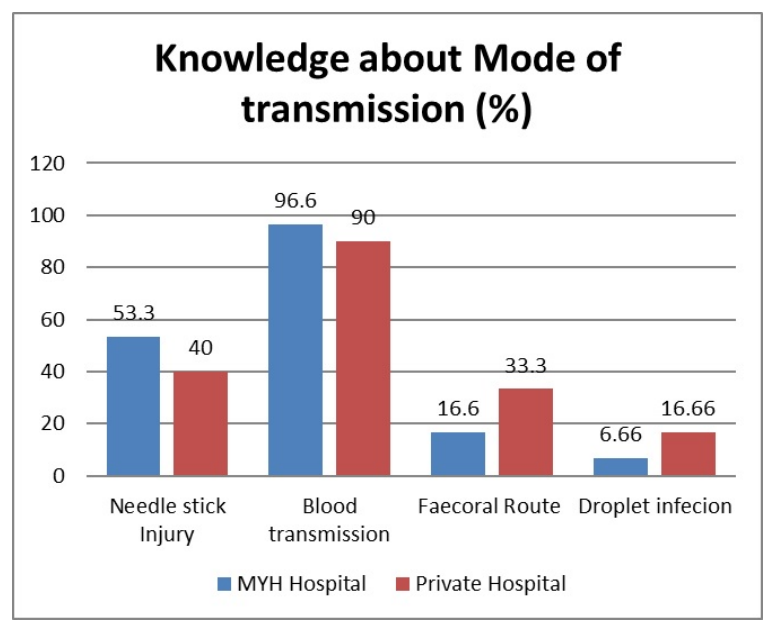

Figure 1: Showing Knowledge about Mode of Transmission of Hepatitis B Infection

*Some Nurses gave Multiple Answer

10 (33.33\%) of MYH nurses and 20 (66.66\%) of $\mathrm{PH}$ nurses considered Operation theatre to be a risky place. 13 (43.3\%) of $\mathrm{MYH}$ and 7 (23.3\%) of $\mathrm{PH}$ considered all

Figure 2: Showing Knowledge about places in hospital that consider to be risky for Hepatitis B Infection

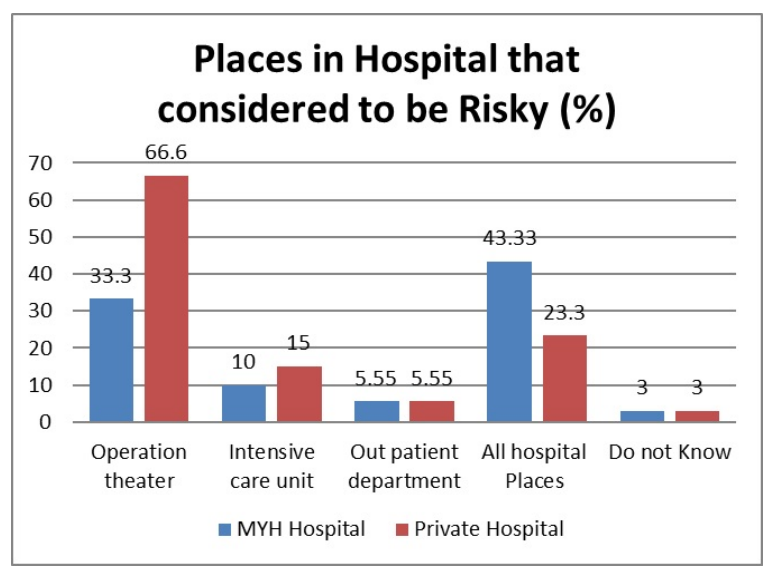

Hospital places to be risky. (Figure 2) 24 (80\%) of MYH nurses and 20 (66.66\%) of $\mathrm{PH}$ considered blood drawing to be more risky. 1 (3.3\%) of $\mathrm{MYH}$ and 25 (83.33\%) of $\mathrm{PH}$ considered wound contact to be more risky. 11 (36.66\%) of MYH and 5 (16.66\%) of $\mathrm{PH}$ nurses were think that recapping of needles to dangerous. (Figure 3)

Figure 3: Showing knowledge about Nursing Intervention that consider to be Risky for Hepatitis B infection

*Some Nurses gave Multiple Answer

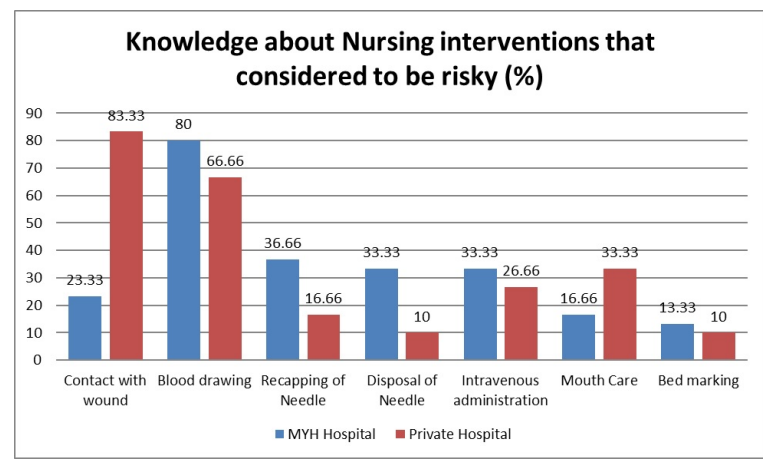

\section{Attitude}

$11(36.67 \%)$ of nurses of MYH and $28(93.33 \%)$ nurses of $\mathrm{PH}$ were vaccinated. 
(Table 3) Out of vaccinated $9(81.82 \%)$ of $\mathrm{MYH}$ nurses and $23(82.15 \%)$ of $\mathrm{PH}$ nurses had complete course of vaccination. (Table 4) 8 (72.73\%) of nurses of $\mathrm{MYH}$ were vaccinated before entering the profession as compared to $4(14.28 \%$ ) of $\mathrm{PH}$. (Table 5)

\section{Table-3: Showing comparison regarding vaccination status*}

\begin{tabular}{|l|l|l|l|l|}
\hline \multirow{2}{*}{ vaccination status } & \multicolumn{2}{|l|}{ MYH Hospital Nurses } & \multicolumn{2}{l|}{ Private Hospital Nurses } \\
\cline { 2 - 5 } & Numbers & Percentage & Numbers & Percentage \\
\hline Yes & 11 & 36.67 & 28 & 93.33 \\
\hline No & 19 & 63.33 & 2 & 6.67 \\
\hline Total & 30 & 100 & 30 & 100 \\
\hline
\end{tabular}

* $x_{2}=18.7 ; \mathrm{df}=1 ; \mathrm{p}$ value $0.000 ;$ statistically significant

Table-4: Showing comparison regarding course of vaccination

\begin{tabular}{|l|l|l|l|l|}
\hline & \multicolumn{2}{|l|}{ MYH Hospital Nurses } & \multicolumn{2}{l|}{ Private Hospital Nurses } \\
\hline Course of vaccination & Numbers & Percentage & Numbers & Percentage \\
\hline Incomplete & 2 & 18.18 & 5 & 17.85 \\
\hline Complete & 9 & 81.82 & 23 & 82.15 \\
\hline Total & 11 & 100 & 28 & 100 \\
\hline
\end{tabular}

$\mathrm{X}_{2}=0.001 ;$ df $=1 ; \mathrm{p}=0.981 ;$ considered statistically non significant

Table-5: Showing vaccinated before or after entering the profession*

\begin{tabular}{|l|l|l|l|l|}
\hline \multirow{2}{*}{ Vaccination Status } & \multicolumn{2}{|l|}{ MYH Hospital Nurses } & \multicolumn{2}{l|}{ Private Hospital Nurses } \\
\cline { 2 - 5 } & Numbers & Percentage & Numbers & Percentage \\
\hline Before & 8 & 72.73 & 4 & 14.28 \\
\hline After & 3 & 27.27 & 24 & 85.72 \\
\hline
\end{tabular}

* $x_{2}=10.6 ; \mathrm{df}=1 ; \mathrm{p}$ value $0.000 ;$ statistically significant

\section{Practice}

10 (33.33\%) of $\mathrm{MYH}$ nurses and 14 (46.6\%) of $\mathrm{PH}$ nurses were exposed to needle stick injury. (Table 6) $1(10 \%)$ of nurses of $\mathrm{MYH}$ and $12(85.7 \%)$ of $\mathrm{PH}$ nurses were vaccinated out of those exposed to needle stick injury. (Table 7) $2(6.66 \%)$ of $\mathrm{MYH}$ nurses and 20 (66.67\%) of $\mathrm{PH}$ nurses wrongly press the point of prick after a needle stick injury. 29 (96\%) of $\mathrm{MYH}$ nurses and 25 (83.3\%) of $\mathrm{PH}$ nurses put antiseptic after a needle stick injury. (Table 8) 9 (30\%) nurses of $\mathrm{MYH}$ and $6(20 \%)$ of $\mathrm{PH}$ had knowledge of post exposure prophylaxis. 26 $(86.6 \%)$ nurses of $\mathrm{MYH}$ and 28 (93.3\%) nurses of $\mathrm{PH}$ follow universal precautions. $100 \%$ nurses of both hospitals follow colour coding for waste disposal.
Table-6: Showing data related to exposure to needle stick injury

\begin{tabular}{|l|l|l|l|l|}
\hline \multirow{2}{*}{$\begin{array}{c}\text { Exposure to needle stick } \\
\text { injury }\end{array}$} & \multicolumn{2}{|c|}{$\begin{array}{c}\text { MYH Hospital } \\
\text { Nurses }\end{array}$} & \multicolumn{2}{c|}{$\begin{array}{r}\text { Private Hospital } \\
\text { Nurses }\end{array}$} \\
\cline { 2 - 5 } & Numbers Percentage & Numbers & Percentage \\
\hline Exposed & 10 & 33.33 & 14 & 46.67 \\
\hline Non Exposed & 20 & 66.67 & 16 & 53.33 \\
\hline Total & 30 & 100 & 30 & 100 \\
\hline
\end{tabular}

$\mathrm{X} 2=1.11 ; \mathrm{df}=1 ; \mathrm{p}=0.292 ;$ Consider statistically non significant

Table-7: Showing vaccinated out of those exposed to needle stick injury*

\begin{tabular}{|l|l|l|l|l|}
\hline \multirow{2}{*}{} & \multicolumn{2}{|c|}{ MYH Hospital Nurses } & \multicolumn{2}{c|}{ Private Hospital Nurses } \\
\cline { 2 - 5 } & Numbers & Percentage & Numbers & Percentage \\
\hline Vaccinated & 1 & 10 & 12 & 85.71 \\
\hline Non vaccinated & 9 & 90 & 2 & 14.28 \\
\hline Total & 10 & 100 & 14 & 100 \\
\hline
\end{tabular}

$* x_{2}=16.69 ; p$ value $0.000 ;$ statistically significant

Table-8: Showing knowledge what does the nursing staff do after a needle stick injury*

\begin{tabular}{|l|l|l|l|l|}
\hline \multirow{2}{*}{} & \multicolumn{3}{|l|}{ MYH Hospital Nurses } & Private Hospital Nurses \\
\cline { 2 - 5 } & Numbers & Percentage & Numbers & Percentage \\
\hline Press the point of prick & 2 & 6.67 & 20 & 66.67 \\
\hline Put Antiseptic & 29 & 96.67 & 25 & 83.33 \\
\hline Inform Ward Sister & 12 & 40 & 3 & 10 \\
\hline Don't do any thing & 3 & 10 & 7 & 23.33 \\
\hline
\end{tabular}

$* x_{2}=5.54 ; \mathrm{df}=3 ; \mathrm{p}$ value $0.000 ;$ statistically significant

\section{Discussion}

This study was conducted in 60 nurses of Indore with 30 nurses of each MY hospital and Private Hospital.

Mean age of nurses was $42.25 \pm 4.2$ years in MY hospital and $34.12 \pm 3.8$ years in Private Hospital. All of them were graduated. $10 \%$ nurses of $\mathrm{MYH}$ and $16.67 \%$ of $\mathrm{PH}$ were married.

\section{Knowledge:}

All the nurses had basic knowledge about agent and host factor of hepatitis B infection. 96.67\% nurses of $\mathrm{MYH}$ and $90 \%$ of $\mathrm{PH}$ knew that hepatitis $\mathrm{B}$ had Blood transmission while $16.67 \%$ of $\mathrm{MYH}$ and $33.3 \%$ of $\mathrm{PH}$ thought that faeco- oral is main mode of transmission. This was comparable to study of Ujwala U. Ukey et al [10] (84.87\%), Patil et al [12] $(96.9 \%)$ and much more study of Maroof et al [13] (35.2\%), Khalid FA et al [14] (21\%). 
$33.33 \%$ nurses of $\mathrm{MYH}$ and $66.67 \%$ of $\mathrm{PH}$ considered Operation theatre as risky place while $43.33 \%$ and $23.33 \%$ nurses of $\mathrm{MYH}$ and $\mathrm{PH}$ respectively; consider all hospital places as risky. Nurses of government hospital were thought that they are at risk which was significantly ( $p=0.018$ ) different from knowledge of nurses of $\mathrm{PH}$. It was comparable to Habib et al [15] (65\%) and Patel et al [12] $(90.2 \%)$.

\section{Attitude:}

In this study $36.67 \% \mathrm{MYH}$ and $93.33 \% \mathrm{PH}$ nurses were vaccinated, out of which more than $80 \%$ were completely vaccinated. This was comparable to study done by $\mathrm{K}$. Djeriri et al [16] shows that in morocco health workers only $55 \%$ are fully vaccinated, Patil et al [12] 96.2\% Auxiliary health care worker are vaccinated, Singhal et al [17] (58.3\%) and Dannetun et al [18] in this $79 \%$ HCWs are vaccinated out of which $40 \%$ were fully vaccinated. $85.52 \% \mathrm{PH}$ nurses and $27.27 \% \mathrm{MYH}$ nurses were vaccinated after entering the hospital. Higher percentage in private institute was mainly due to Hospital policy. Reason of non vaccination at government hospital was unavailability (31.5\%) and negligence $(10.52 \%)$. Reason of non vaccination in private hospital was negligence (100\%) (Figure 4 )

\section{Practice:}

33.33\% $\mathrm{MYH}$ nurses and $46.66 \% \mathrm{PH}$ nurses were exposed to needle stick injury. Knowledge about course of action revealed that $96 \% \mathrm{MYH}$ and $83.83 \% \mathrm{PH}$ nurses put antiseptic while $10 \% \mathrm{MYH}$ and $23.33 \% \mathrm{PH}$ nurses do not do anything. In study by Patel et al [12] $40.5 \%$

AHCWs knew the correct course of action after a needle stick injury. 70\% $\mathrm{MYH}$ nurses and $80 \% \mathrm{PH}$ nurses does not aware correct procedure of post exposure prophylaxis. All the nurse of Government and private Hospital follow standard method of bio waste management.

This study was carried out with 60 nurses who was not representative of all the nurses of various hospitals in Indore District, needs more sample size to be incorporated which unfortunately was not included due to time constraint.

The findings in the present study reiterate the need for refresher training at regular interval of nurses of both government and private hospital. There should be compulsory provision for hepatitis $B$ vaccination before entering to hospitals.
Health education campaigns and training programs should be regularly organized for nurses on hospital born infection control.

This study was concluded as vaccination was more in private institution than government institution. Nurses of government and private hospital had knowledge about correct mode of transmission, hospital places and intervention considered to more risky to them. Awareness amongst MY Hospital nurses regarding them being at high risk of hepatitis $B$ is more than nurses of Private hospital. Main reason or the acceptance of vaccination is Hospital policy. Knowledge about post exposure prophylaxis and correct action after needle stick injuries was relatively less in nurses of both institutions.

Awareness, precaution, and protection should be advocated in order to prevent the nosocomial spread of Hepatitis B Infection. Therefore, there is a need for well planned and clear policies for HBV screening, vaccination, and serological response checkups for all HCWs [12].

\section{Reference}

01. Lee WM. Hepatitis B virus infection. N Engl J Med. $1997 ; 337 ; 1733-45$.

[Crossref]

02. Liaw YF, Chu CM. Hepatitis B virus infection. The Lancet. 2009;373(9663)582-92.

[Crossref]

03. Zheng $Y$, Huang $Z$, Chen $X$, Tian $Y$, Tang J, Zhang $Y i$ et al. Effects of Telbivudine Treatment on the Circulating CD4+ T-Cell Subpopulations in Chronic Hepatitis B Patients. Mediators of Inflammation. 2012;789859.

[Crossref]

04. Saini R, Saini S, Sugandha RS. Knowledge and awareness of Hepatitis $B$ infection amongst the students of Rural Dental College, Maharashtra, India. Ann Nigerian Med. 2010;4;18-20.

[Crossref]

05. World Health Organization. Country Office for India, Core Programme Clusters. Family and community health, Hepatitis B.

Available at: [Article] [Crossref]

06. Singh A, Jain S. Prevention of Hepatitis B; knowledge and practices among Medical students. Healthline. $2011 ; 2(2) 8-11$.

[Crossref] 
07. Shepard CW, Simard EP, Finelli L, Fiore AE, Bell BP. Hepatitis B virus infection- epidemiology and vaccination. Epidemiol Rev. 2006;28;112-25. [Crossref]

08. Rawat S, Sharma N, Kumar M, Ahmed NK, Sailwal S, Sharma $S$, et al. Quantification of HBV DNA and its Impact on viral load monitoring. J Pharm Biomed Sci. 2013;2;75-80. [Crossref]

09. Singhal V, Bora D, Singh S. Hepatitis B in health care workers- Indian Scenario. J Lab Physicians. 2009; $1 ; 41-8$.

[Crossref]

10. Taneja N, Biswal M. Safe disposal of infectious waste. Indian perspective Journal of Hospital Infection. 2006;62(4)525-26.

[Crossref]

11. Ukey UU, Dash S, Sankaram KR, Naidu NA, SriVidya R. "A Cross-sectional study of awareness about hepatitis $b$ among nursing students of mims college at vizianagaram, andhra Pradesh. Int J Cur Res Rev. Oct 2012;04(20)149- 155.

[Crossref]

12. Patil S, Rao RS, Agarwal A. Awareness and risk perception of hepatitis $B$ infection among auxiliary healthcare workers. J Int Soc Prevent Communit Dent. 2013;3;67-71.

[Crossref]

13. Maroof KA, Bansal R, Parashar P, Sartaj A. Do the medical, dental and nursing students of first year know about hepatitis B?- A study from a university of North India. J Pak Med Assoc. 2012;62(1)25-7.

[Crossref]
14. Khalid FA, Eltayeb AA. Elbadawi NEE (2013) Awareness and Knowledge of Hepatitis $B$ and HIV/AIDS, Among the University of Kassala Students, Sudan. J AIDS Clin Res. 4;194.

doi: 10.4172/2155-6113.1000194 [Crossref]

15. Habib F, Khan DK, Shan-E-Abbas, Bhatti F, Zafar A. Knowledge and beliefs among health care workers regarding hepatitis $B$ infection and needle stick injuries at a tertiary care hospital, Karachi. J Coll Physicians Surg Pak. 2011;21;317-8.

[Crossref]

16. Djeriri K, Laurichesse $H$, Merle JL, Charof $R$, Abouyoub A, Fontana L, Benchemsi N, Elharti $E$, Aouad R, Chamoux A, Beytout J. "Hepatitis B in Moroccan health care workers". Occupational Medicine. 2008;58;419-424.

[Crossref]

17. Singhal V, Bora D, Singh S. Prevalence of Hepatitis $B$ virus infection in healthcare workers of a tertiary care centre in India and their vaccination status. J Vaccines Vaccin. $2011 ; 2 ; 118$.

[Crossref]

18. Dannetun E, Tegnell A, Torner A, Giesecke J. Coverage of hepatitis $B$ vaccination in Swedish healthcare workers. J Hosp Infect. 2006;63;201-4.

[Crossref] 